Kurepin Vyacheslav, Senior Lecturer, Professional Teaching Methods Department, Mykolayiv National Agrarian University, Mykolayiv, Ukraine

ORCID ID: 0000-0003-4383-6177

e-mail: ypinc@ukr.net

Kurepin Dmitry, Administrator of Roller Center LLC

\title{
Public administration in the field of civil protection and security of life in the conditions of local self-government reform and decentralization of power
}

Introduction.The strategy of socio-economic development of Ukraine defines the need to protect the population from emergencies as one of the most important directions of state policy implementation at the present stage, represented by the civil protection system. The main task of preparation to the civil protection of the Ship district of Mykolayiv for 2020 is to develop specific tasks and measures for the implementation of state policy aimed at ensuring the safety and protection of the population and territories, material and cultural values and the environment from emergencies of anthropogenic and natural character in peaceful time and special period.

Appointment. The purpose of this article is to systematize the priorities of local governments, enterprises, institutions and organizations, regardless of ownership, aimed at the effective implementation of state policy in the field of protection of the population and territories from anthropogenic and natural emergencies, prevention and prompt response to them. It will allow to draw up and implement scientifically substantiated complex programs of ensuring safe socio-economic development of objects and territories, including the Ship district of Mykolayiv.

Results. We are convinced that local authorities, civil protection specialists should thoroughly analyze the effectiveness and reliability level of the territorial subsystem of the unified civil protection system and evaluate the activity of all subjects of civil protection in the area to ensure public safety in emergency situations. The need for this step is dictated by the presence of a number of objective and subjective factors, including: the increase in the number and magnitude of natural emergencies, as well as the damage caused by them; significant deterioration of the systems of emergency control and prevention of emergencies, which threatens emergencies of anthropogenic nature; reducing the quality of supervision of potentially dangerous objects and compliance with fire safety rules; insufficient amount of forces and means necessary to monitor the state of dangerous natural phenomena and insufficient effectiveness of actions at localization of disasters in their initial stage; insufficient level of readiness of civil defense forces due to their low level of logistical support; unsatisfactory resolution of issues related to the construction of new, state-of-the-art protective structures for sheltering the population.

Conclusions. Development and application of these and other types of public administration mechanisms in the field of CS combined with the opportunities arising from the requirements of the regulatory legal system, the state of the economy, create the basis for the effective functioning of the system of protection of the population and territories from the National Emergency, allow to draw up and implement scientifically sound integrated programs ensuring safe socio-economic development of facilities and territories, including the Ship district of Mykolayiv.

Keywords: ensuring public safety; civil protection system; government; emergency situations; life spheres.

\section{Удк 351:32}

Курепін В. М., старший викладач кафедри методики професійного навчання, Миколаївський національний аграрний університет, Миколаїв, Україна

Курепін Д. В., адміністратор ТОВ «Роллер Центр»

\section{Державне управління у сфері цивільного захисту та безпеки життєдіяльності в умовах реформування місцевого самоврядування та децентралізації влади}

Стратегія соціально-економічного розвитку України визначає необхідність захисту населення від надзвичайних ситуацій як один із найважливіших напрямів реалізації державної політики на сучасному етапі, що здійснюється системою цивільного захисту. Головним завданням з підготовки цивільного захисту Корабельного району м. Миколаєва на 2020 рік вважається розроблення конкретних завдань та заходів щодо реалізації державної політики, спрямованої на зміцнення безпеки та захисту населення і територій, матеріальних і культурних цінностей та довкілля від надзвичайних ситуацій техногенного та природного характеру у мирний час та в особливий період.

Мета цієї статті - систематизація пріоритетних завдань державного управління у сфері цивільного захисту та безпеки життєдіяльності в умовах реформування місцевого самоврядування та децентралізації влади, що дозволить складати та реалізовувати науково обгрунтовані комплексні програми забезпечення безпечного соціальноекономічного розвитку об'єктів і територій, у тому числі і Корабельного району м. Миколаєва.

Переконані, що місцевим органам державної виконавчої влади, фахівцям цивільного захисту слід детально проаналізувати ефективність і рівень надійності територіальної підсистеми єдиної системи цивільного захисту та 
дати оцінку діяльності усім суб'єктам сфери цивільного захисту району по зміцненню безпеки населення в умовах надзвичайних ситуацій. Необхідність цього кроку продиктована наявністю ряду об'єктивних і суб'єктивних чинників, серед яких: зростання кількості та масштабів надзвичайних ситуацій природного характеру, а також шкоди від них; значна зношеність систем аварійного контролю та запобігання надзвичайних ситуацій, що загрожує виникненням надзвичайних ситуацій техногенного характеру; зниження якості нагляду за станом потенційно небезпечних об'єктів та дотриманням правил пожежної безпеки; недостатня кількість сил і засобів, необхідних для спостереження за станом небезпечних природних явищ і недостатня ефективність дій при локалізації лих в їх початковій стадії; недостатній рівень готовності сил цивільного захисту через низький рівень їх матеріально-технічного забезпечення; незадовільне розв'язання питань, пов'язаних з будівництвом нових, станом наявних захисних споруд для укриття населення.

Розробка і застосування вказаних і інших видів механізмів державного управління у сфері цивільного захисту у поєднанні з можливостями, що базуються на вимогах нормативної правової системи, стану економіки, створюють базу для ефективного функціонування системи захисту населення і територій від надзвичайних ситуацій, дозволяють складати і реалізовувати науково обгрунтовані комплексні програми забезпечення безпечного соціально-економічного розвитку об'єктів і територій, у тому числі і Корабельного району м. Миколаєва. ситуації.

Ключові слова: забезпечення безпеки населення; система цивільного захисту; органи управління; надзвичайні

Formulation of the problem. The strategy of socioeconomic development of Ukraine defines the need to protect the population from emergencies as one of the most important directions of state policy implementation at the present stage, represented by the civil protection system. Local authorities, civil protection specialists should analyze in detail the effectiveness and reliability level of the territorial subsystem of the unified civil protection system and evaluate the activity of all subjects of civil protection in the area to ensure public safety in emergency situations [1]. According to the analysis, to develop specific tasks and measures for the implementation of the state policy aimed at ensuring the safety and protection of the population and territories, material and cultural values and the environment from technogenic and natural emergencies in peacetime and in a special period.

More than ever, there is a high likelihood of risks to the safety of life of the population, in particular, due to natural and man-made emergencies and fires. The forecast shows that they can pose a great threat to the population, objects of economy, territories, can lead to great material losses, have long lasting environmental and social consequences. The need to ensure that the civil defense system is ready in the event of possible natural and manmade emergencies is beyond doubt. The relevance of research aimed at improving public policy in the field of civil protection in accordance with the requirements of modernity, efficiency and level of reliability of the territorial subsystem of a single civil protection system for ensuring public safety in emergency situations is determined and determined.

Analysis of recent research and publications. Establishment and construction of a modern Europeantype public administration system in Ukraine (decentralization of power) through ratification by the Verkhovna Rada of Ukraine on July 15, 1997 of the European Charter of Local Self-Government has enshrined the fundamental principles of organization and functioning of local self-government, obliged Ukraine to join the international standard. The Strategy of Reforming the State Civil Protection Administration approved by the
Cabinet of Ministers is being implemented in Ukraine, the implementation of which is envisaged for the years 20172020. The distribution of power during the implementation of civil protection measures of the population and territories at the central and regional levels; changes in the territorial organization of power in Ukraine, reform of local self-government and decentralization of power; interaction of functional and territorial subsystems of the unified state system of civil protection in case of emergencies, etc are specified.

In accordance with the requirements of the current legislation and the planned reform of the State Emergency Service of Ukraine, a simple and logical system of local self-government should be created, capable of ensuring a comfortable and safe life for citizens [3]. Public administration issues in the field of civil protection and life safety in the context of local self-government reform and decentralization of power were investigated in the scientific papers and articles by S. Andreev, V. Bakumenko, V. Bodelan, P. Volyansky, O. Vyshnevskaya, Y. Drevalya, L. Zhukov, Y. Korolyuk, V. Kostenko, V. Mikhailuk, E. Romanchenko, V. Sadkovo, A. Semenchenko, O. Trush, O. Fedorchak, I. Shpilev and others.

Scientists and practitioners have focused on the functions and tasks of state civil protection systems, their organizational structures, specific mechanisms of implementation of certain civil protection measures at different administrative and territorial levels. At the same time, the effects of technogenic and natural emergencies on the formation and operation of state-level civil protection systems are poorly understood. The research on this issue is fragmentary, and the nature of the scientific results obtained by the authors regarding the problems of functioning of the unified state system of civil protection does not allow to draw a more or less complete picture of this problem.

Formulation of research goals. The purpose of this article is to systematize the priorities of local governments, enterprises, institutions and organizations, regardless of ownership, aimed at the effective implementation of state policy in the field of protection of the population and territories from anthropogenic and 
natural emergencies, prevention and prompt response to them. It will allow to draw up and implement scientifically substantiated complex programs of ensuring safe socioeconomic development of objects and territories, including the Ship district of Mykolayiv.

Outline of the main research material. Sustainable socio-economic development of the territorial community and increasing the well-being of its population are almost impossible without addressing the issues of human life safety and protection against emergencies. Protection of the population, territories, environment and property from emergencies by preventing such situations, eliminating their consequences and providing assistance to the victims in peacetime and during a special period is created by a unified state system of civil protection within the functional, territorial systems and their links [4 ]. It implements the state policy in the field of civil protection.

Under the state administration on protection of the population, territories and environment from technogenic and natural emergencies it is proposed to consider as activities of bodies and institutions of all branches of state power that influence the interaction of functional and territorial subsystems of the unified state system of civil protection in case of emergencies. The state policy of Ukraine in the field of local self-government is, first of all, based on the interests of residents of territorial communities and provides for radical changes and systemic reforms, decentralization of power, that is, transfer from the bodies of executive power to the bodies of local self-government a considerable part of powers, resources and responsibilities [2].

One of the priority tasks of local self-government bodies, enterprises, institutions and organizations, regardless of ownership and subordination, is the implementation of measures aimed at the effective implementation of state policy in the field of protection of the population and territories from emergencies of manmade and natural character, prevention and prompt response to them.

Ensuring the implementation of state policy in the field of civil protection at the regional level is carried out by the territorial subsystem of a unified state system of civil protection, which includes links of united territorial communities [5]. When talking about the unit of the integrated territorial subsystem, it must ensure the establishment and operation of civil protection management and defense forces. Accordingly, the chairman of the united territorial community becomes the head of the unit of the united territorial community of the territorial subsystem of the unified state civil protection system. This link should provide information and information to the public about the threat and emergencies, shelter the population in protective structures of civil protection, its evacuation to safe areas, accommodation, provision of livelihoods of victims of emergencies, the organization of emergency response and liquidation. These are the main tasks of the united territorial communities in the field of civil protection.

The main efforts in realization of the main task of the Administration of the Ship district of the Mykolayiv City council focus on: providing readiness for actions of bodies of management of civil protection forces of area, the city link of the Mykolayiv territorial subsystem of the uniform state system of civil protection; conducting preventive measures in the field of population protection, man-made and fire safety, in order to reduce the risks of emergencies and reduce human and material losses; development of the created potential of population protection means, accumulation of material reserves intended for the prevention and elimination of emergencies; development and implementation of measures aimed at accident-free functioning of potentially dangerous objects, systems of life support of the Ship district of Mykolayiv.

Today it is clear to everyone that sustainable development of the country can be achieved not so much by eliminating the consequences of natural and manmade emergencies, but, first of all, by their timely forecasting and prevention [6]. The implementation of such a strategy requires the widespread adoption of methods and means of forecasting and preventing emergencies, and, above all, assessing the risk of their occurrence, developing preventive measures and ensuring preparedness for them. Features of application of precautionary measures to bring to the population signals and notices of civil protection management bodies in the Ship district of Mykolayiv about threat or occurrence of emergency situations, dangerous events are summarized in table 1.

The operational readiness of the urban parts of the territorial subsystem of the single state civil protection system includes the organized export (export) of the population from an emergency zone or zone of possible harm in the event of imminent threat to his life and causing harm to health; placement of the population outside the emergency areas; Organized removal of material and cultural property if there is a risk of damage or destruction [1]. Features of application of measures on evacuation of the population, material values of the Ship district of Mykolayiv are summarized in table 2 
Електронне наукове фахове видання з економічних наук "Modern Economics», №19 (2020), 94-100 https://modecon.mnau.edu.ua | ISSN 2521-6392

Table 1 Bringing to the population signals and messages of civil protection management bodies in the Ship district of Mykolayiv about threat or occurrence of emergency situations, dangerous events

\begin{tabular}{|l|l|}
\hline \multicolumn{1}{|c|}{ Conditions of the situation } & \multicolumn{1}{c|}{ List of practical works } \\
\hline & $\begin{array}{l}\text { 1. Review and clarify the Emergency Response Plans and other documents regarding the } \\
\text { organization and carrying out of the notification of threat or emergencies occurrence, } \\
\text { dangerous events. Make changes to the artists. } \\
\text { 2. To check and to clarify the list of officials of public authorities, operational-duty and } \\
\text { dispatch services, heads of enterprises, institutions and organizations for centralized } \\
\text { notification, determining the order of their notification. } \\
\text { 3. Organize the verification of the technical readiness (efficiency) of alert systems. } \\
\text { 4. Take measures to inform the population, which cannot be notified by technical means. } \\
\text { 5. Take measures to apply alternative means of alert in case of failure of technical means } \\
\text { of alert. } \\
\text { 6. Organize a check on the readiness of the operational duty and dispatch services for } \\
\text { the implementation of the process of notification of threats or emergencies, dangerous } \\
\text { events. } \\
\text { 7. If necessary, take measures regarding additional equipment of settlements by } \\
\text { loudspeakers. }\end{array}$ \\
\hline $\begin{array}{l}\text { During emergencies, dangerous } \\
\text { events }\end{array}$ & $\begin{array}{l}\text { 1. Organize the recovery of the alert system (after the active phase of an emergency, a } \\
\text { dangerous ent). Organize control over the implementation of the notification of the beginning of an } \\
\text { emergency, a dangerous event. }\end{array}$ \\
\hline $\begin{array}{l}\text { During the recovery period } \\
\text { after the end of emergencies, } \\
\text { dangerous events }\end{array}$ & $\begin{array}{l}\text { 1. Organize a review and evaluate the state of alert systems, take measures to restore it. } \\
\text { 2. Organize an analysis of the operation of the emergency alert system, a dangerous } \\
\text { event, as a result of which measures should be taken to improve it. }\end{array}$ \\
\hline
\end{tabular}

Source: created and supplemented by author based on materials [1]

Table 2 Features of application of measures on evacuation of the population, material values of the Ship district of Mykolayiv by civil protection forces of administration of the Ship district of the Mykolayiv City Council of a city link of the Mykolayiv territorial subsystem of the uniform state system of civil protection

\begin{tabular}{|l|l|}
\hline \multicolumn{1}{|c|}{ Conditions of the situation } & \multicolumn{1}{c|}{ List of practical works } \\
\hline $\begin{array}{l}\text { During the threat of emergencies, } \\
\text { dangerous events }\end{array}$ & $\begin{array}{l}\text { 1. Review and clarify the Emergency Response Plans and other documents } \\
\text { regarding the organization and conduct of notification of threat or emergencies, } \\
\text { hazardous events. }\end{array}$ \\
\hline & $\begin{array}{l}\text { 1. Make a decision on evacuation of the population and material assets. } \\
\text { 2. Introduce a separate section on evacuation in case of emergency, dangerous } \\
\text { events of the Civil Protection Plan for a special period. } \\
\text { 3. Establish control over the implementation of evacuation measures and the } \\
\text { implementation of a separate section on evacuation in case of emergency, } \\
\text { dangerous events of the Civil Protection Plan for a special period. }\end{array}$ \\
$\begin{array}{l}\text { During emergencies, dangerous } \\
\text { events }\end{array}$ & $\begin{array}{l}\text { and reception points of evacuation, road safety on evacuation routes. } \\
\text { 5. To manage the processes of evacuation of the population, material values, } \\
\text { reception and placement of the population in safe areas. }\end{array}$ \\
\hline $\begin{array}{l}\text { During the recovery period after the } \\
\text { end of the threat of emergencies, } \\
\text { dangerous events }\end{array}$ & $\begin{array}{l}\text { 1. Organize the return of people to their territories, objects. } \\
\text { 2. To clarify the measures of a separate section on emergency evacuation in case } \\
\text { of emergency, dangerous events of the Civil Protection Plan for a special period, } \\
\text { the possibility of evacuation authorities to perform assigned tasks in the event of } \\
\text { an emergency, dangerous events, taking into account the experience gained. }\end{array}$ \\
\hline
\end{tabular}

Source: Created and supplemented by author based on materials [1]

The priority direction of implementatiion of the state policy in creating conditions of safe life of the population of the Ship district of the city of Mykolayiv is defined as coordination and maintenance of actions of governing bodies and civil protection forces of all levels in response to emergencies or threat of its occurrence in the territory of the area. Features of application of system of preventive measures for shelter of the population in protective constructions in case of emergencies, dangerous events by bodies of management of civil protection of the Ship district of Mykolayiv are summarized in table 3 . 
Електронне наукове фахове видання з економічних наук "Modern Economics», №19 (2020), 94-100 https://modecon.mnau.edu.ua | ISSN 2521-6392

Table 3 Features of application of preventive measures system for shelter of the population in protective constructions in case of emergencies, dangerous events by bodies of management of civil protection in the Ship district of Mykolayiv

\begin{tabular}{|l|l|}
\hline \multicolumn{1}{|c|}{$\begin{array}{c}\text { Conditions of the } \\
\text { situation }\end{array}$} & \multicolumn{1}{c|}{ List of practical works } \\
\hline $\begin{array}{l}\text { 1. To organize the readiness of civil protection structures of all types to protect human beings, in } \\
\text { particular: } \\
\text { a) organize a check on the readiness of civil protection structures for sheltering the population; } \\
\text { b) to prepare for the protection of people of dual purpose structures and the simplest shelters: } \\
\text { d) provide dual-use storage and facilities with medicines, drinking water and food, hygiene } \\
\text { products, dry closets; } \\
\text { e) restore unusable civil protection structures and their equipment; }\end{array}$ \\
$\begin{array}{l}\text { e) to decide on the application for the protection of people of the rapidly erecting civil protection } \\
\text { emergencies, } \\
\text { dangerous events } \\
\text { g) mark civil protection structures with information signs and set direction and distance indicators } \\
\text { to the nearest protective structure; } \\
\text { g) Organize the distribution of the urban population to the Dual-purpose Buildings Fund, taking } \\
\text { into account their capacity. } \\
\text { 2. Organize with the involvement of the mass media to inform the population about the locations } \\
\text { of the civil protection protective structures and the procedure for their concealment, as well as the } \\
\text { rules of conduct in civil protection protective structures. }\end{array}$ \\
\hline $\begin{array}{l}\text { During emergencies, } \\
\text { dangerous events }\end{array}$ & $\begin{array}{l}\text { 1. Ensure with the beginning of the active phase of emergencies, dangerous events informing the } \\
\text { population about the need for shelter in protective structures. }\end{array}$ \\
\hline $\begin{array}{l}\text { During the recovery } \\
\text { period after the end } \\
\text { of the threat of } \\
\text { emergencies, } \\
\text { dangerous events }\end{array}$ & $\begin{array}{l}\text { 1. To organize, as necessary, repair and restoration of civil protection structures. } \\
\text { 2. Organize the study of the work of personnel in the maintenance of civil protection structures } \\
\text { and the ability of civil protection structures to protect the public. Take measures to improve the } \\
\text { shelter of the population in civil protection structures. }\end{array}$ \\
\hline
\end{tabular}

Source: created and supplemented by author based on materials [1]

Features of conducting rescue and other urgent works on elimination of consequences of emergencies, dangerous events by civil protection forces of the

Council of city communication of the Mykolayiv territorial subsystem of the uniform state civil protection system are summarized in table 4. Administration of the Ship district of the Mykolayiv City

Table 4 Features of carrying out of emergency rescue and other urgent works on liquidation of consequences of emergency situations, dangerous events by civil protection forces of administration of the Ship district of the Mykolayiv city council of a city link of the Mykolayiv territorial subsystem of the uniform state system of civil protection

\begin{tabular}{|l|l|}
\hline \multicolumn{1}{|c|}{$\begin{array}{c}\text { Conditions of the } \\
\text { situation }\end{array}$} & \multicolumn{1}{c|}{ List of practical works } \\
\hline & $\begin{array}{l}\text { 1. Organize: } \\
\text { - clarification of the Emergency Response Plans regarding the involvement of emergency rescue } \\
\text { units in carrying out emergency rescue and other urgent work to eliminate the consequences of } \\
\text { emergencies, dangerous events, as well as their distribution by areas of responsibility; } \\
\text { - introduction of amendments to the administrative documents on the use of emergency rescue } \\
\text { units of civil protection (if necessary) and their actions for carrying out emergency rescue and } \\
\text { other urgent works; } \\
\text { - additional equipment, if necessary, of emergency-rescue formation of civil protection by } \\
\text { special and other emergency-rescue equipment; } \\
\text { - providing rescuers of emergency rescue units of civil protection by means of personal } \\
\text { protection. } \\
\text { 2. To work out in advance the issue of setting up a special commission for the elimination of the } \\
\text { consequences of emergencies, dangerous events, to appoint the head of work on the elimination } \\
\text { of the consequences of emergencies. Prepare draft regulatory documents. } \\
\text { dangerous events. } \\
\text { 3. Organize a review of the creation of specialized civil protection services and their readiness to } \\
\text { perform the assigned tasks. }\end{array}$ \\
\hline $\begin{array}{l}\text { During emergencies of } \\
\text { dangerous events. }\end{array}$ & $\begin{array}{l}\text { 1. Organize the keeping of the conducted emergency and rescue and other urgent works on } \\
\text { elimination of consequences of emergencies, dangerous events. }\end{array}$ \\
\hline $\begin{array}{l}\text { During the recovery } \\
\text { period after an } \\
\text { emergency, a } \\
\text { dangerous event. }\end{array}$ & $\begin{array}{l}\text { 1. Take measures to inspect the territory where emergency rescue and other urgent work was } \\
\text { done to eliminate the consequences of emergencies and dangerous events. } \\
\text { 2. Organize the collection and processing of information on the defective or destroyed objects } \\
\text { life support of the population and draw up a plan of priority restoration works on such objects. }\end{array}$ \\
\hline
\end{tabular}

Source: created and supplemented by author based on materials [1] 
The coordinating bodies in the sphere of realization of the state policy in creation of conditions of safe life activity of the population in the territory of the Ship area are the commission on technogenic-ecological safety and emergencies of the Ship district of Mykolayiv and the sector on emergency situations and civil protection of the population in the Ship area management of situations and civil protection of the population of the Mykolayiv city council which should provide implementation of civil protection measures in the territory of Ship district of Mykolayiv; performance of tasks by bodies of civil protection forces management of administration of the Ship district in the Mykolayiv City Council of city link of the Mykolayiv territorial subsystem of the uniform state civil protection system.

Adopted on October 2, 2012, the Civil Protection Code of Ukraine (the Code), as the only systematic legislative act on civil protection, defined civil protection as a function of the state aimed at protecting the population, territories, environment and property from emergencies. The Code empowers public authorities, local governments, businesses, institutions and organizations, regardless of ownership.

In order to ensure compliance with the requirements of the Civil Protection Code of Ukraine, acts of the President of Ukraine, the Cabinet of Ministers of Ukraine, the Regulations on the Administration of the Ship district of the Mykolayiv City Council, approved by the decision of the Mykolayiv City Council of 23.02.2017 No. 16/32 other administrative documents in the field of civil protection Civil Defense Forces of all levels in response to, or threat of emergencies in the Ship district shall ensure timely implementation of plans for civil protection measures, in particular aimed at protecting the population and territories from emergencies and preventing them from occurring, ensuring man-made and fire safety; the development in the relevant territory of measures aimed at ensuring the sustainable functioning of economic entities in a special period [7].

Among the existing dangers for the Ship district, natural and man-made are the most significant. Due to their persistent nature, they can generate a number of other threats in important areas of the district's livelihood and thus complicate the resolution of acute problems at both regional and local levels [8]. Therefore, the training of civilian authorities and civil defense forces is crucial.

In accordance with the requirements of the Resolution of the Cabinet of Ministers of Ukraine of 26.06.2013 No. 443 "On Approval of the Procedure for Preparation for Action by Appointment of Governing Bodies and Civil Defense Forces", Resolution of the Cabinet of Ministers of Ukraine of 26.06.2013 No. 444 "The Procedure of Exercising Public Emergency Management" training of management and civil protection authorities, training of management personnel and specialists whose activities are connected with the organization and implementation of civil protection measures are constantly organized in the area enterprises, institutions and organizations. This training is carried out in a network of units of the training and methodological center of civil protection and safety of life in the Mykolayiv region, where functional training in the field of civil protection is conducted $[9,10]$. Teachers of the Center are actively involved in the process of advising the heads and deputies of the heads of civil protection of the objects responsible for civil protection issues. Such consultations are provided during scheduled sessions at the Center's structural units.

In addition to theoretical training, the heads and deputies of the heads of civil defense of the objects in the Ship district of the Mykolayiv city had the opportunity to take part in practical actions in the process of conducting trainings of the bodies and forces of civil protection of the territorial subsystem of the unified state system of civil defense, command-staff exercises and trainings, civil exercises on civil protection. So, for example, this year representatives of the district objects took part during training of management bodies and civil protection forces on actions in case of emergencies at LLC "Mykolayiv Alumina Plant" and during training of control bodies and civil protection forces of the local unit of the territorial subsystem of the uniform state system of civil protection in the Mykolayiv district concerning actions in case of emergencies on bases of storage (warehouses) of fireexplosive materials which are located in Ship district.

The mechanism of public administration allows to implement specific directions of public policy, in accordance with the spheres of public activity. It should be noted that the executive and local self-government bodies of the Ship District are constantly carrying out measures aimed at the implementation of state policy in the field of protection of the population and territories from emergency situations of technogenic and natural character, creating the proper conditions for safe life of the population [11].

One of the important mechanisms of public administration is considered to be a legal mechanism consisting of a set of legal means by which the behavior of subjects of public relations is brought into compliance with the requirements and permits contained in the rules of law [12]. This is a necessary condition for the functioning of the activity of state authorities of the Ship district in Mykolayiv. It is the state, as an apparatus of power, which forms the legal space through which state policy is implemented in the sphere of ensuring the functioning of the state system for prevention and response to emergencies; ensuring the safety of the population and the environment, preventing and eliminating emergencies; increase the stability of the operation of objects in emergency situations; logistical and financial support, creation of emergency reserve funds; state supervision and control over the implementation of measures to ensure the safety of the population and territories from natural and man-made disasters and catastrophes.

Conclusions. Thus, the development and application of these and other types of public administration 
mechanisms in the field of civil protection, combined with the opportunities arising from the requirements of the regulatory legal system, the state of the economy, create the basis for the effective functioning of the system of the population protection and territories from emergencies, allow to make and to implement scientifically substantiated complex programs of providing safe socioeconomic development of objects and territories, including the Ship district of Mykolayiv.
Further development of a modern and powerful civil protection system in Ukraine, improvement of public administration in this area require additional organizational and practical measures to be taken to resolve the existing issues. This important work will contribute to the stable social development of the society, further improving the safety of life of the population.

\section{References:}

1. Verkhovna Rada of Ukraine (2012). Code of Civil Protection of Ukraine (Act № 5403-VI, October 2). Retrieved from https://zakon.rada.gov.ua/laws/show/5403-17 [in Ukrainian].

2. The Council of Europe (1985). European Charter of Local Self-Government. Strasbourg, October 15. Retrieved from https://zakon.rada.gov.ua/laws/show/994_036 [in Ukrainian].

3. Kotykova, O. I. \& Babych, M. M. (2017). Vprovadzhennia ievropejs'koho dosvidu sotsial'noho vkliuchennia iak element sotsial'noi rehional'noi polityky. Derzhavne upravlinnia: vdoskonalennia ta rozvytok, 9. Retrieved from http://dspace.mnau.edu.ua/jspui/handle/123456789/2610 [in Ukrainian].

4. Sadkovyj, V. P., Romin, A. V. \& Ostroverkh, O. O. (2013). Derzhavne upravlinnia v haluzi tsyvil'noho zakhystu v Ukraini: normatyvno-pravovyj aspekt. Kharkiv : TOV «Oberih» [in Ukrainian].

5. Cabinet of Ministers of Ukraine (2017). On approval of the Strategy for reforming the State Emergency Service of Ukraine (Decree No. 61-p., January 25. Retrieved from www.zakon.rada.gov.ua/laws/show/61-2017-p. [in Ukrainian].

6. Voloshynovs'kyj, S. V. \& Vyshnevs'ka, O. M. (2016). The essence, components and threats to the industrial security of the state. Bukhhalters'ko-analitychne ta finansove zabezpechennia diial'nosti sub'iektiv hospodariuvannia: natsional'nyj, hlobalizatsijnyj ta ievrointehratsijnyj aspekty. [Accounting, analytical and financial support for the activities of economic entities: national, globalization and European integration aspects], Materialy mizhnarodnoi konferentsii naukovo-doslidnoi praktyky [Proceedings of the International Conference on Research Practice]. Mykolayiv: MNAU, 70-74. Retrieved from http://dspace.mnau.edu.ua/jspui/handle/123456789/3046 [in Ukrainian].

7. The Nikolaev city council (2017). Provision on administration of the Ship district of the Nikolaev city council. Retrieved from https://mkrada.gov.ua/documents/26076.html [in Ukrainian].

8. Vyshnevs'ka, O. M., Bobrovs'ka, N. V. \& Savarina, I. P. (2015). Ekolohichna bezpeka. Mykolaiv: MNAU. Retrieved from http://dspace.mnau.edu.ua/jspui/handle/123456789/3046 [in Ukrainian].

9. Cabinet of Ministers of Ukraine (2013). Approval of the Procedure for Preparation for Action by Appointing Governing Bodies and Civil Defense Forces (Decree No. 443, June 26). Retrieved from https://zakon.rada.gov.ua/laws/show/443-2013-ח [in Ukrainian].

10. Cabinet of Ministers of Ukraine (2013). The procedure for conducting public emergency training (Decree No. 444, June 26). Retrieved from https://zakon.rada.gov.ua/laws/show/444-2013-n [in Ukrainian].

11. Kostenko, V. O. (2014). Local self-government reform as an effective mechanism for raising the level of civil protection of territorial communities. Aspekty derzhavnoho upravlinnia, 3-4 (5-6), 119-126 [in Ukrainian].

12. Kurepin, V. M. \& Horbunov, K. M. (2018). Integrated enterprise security as part of the management system. Aktual'ni pytannia tekhnohennoi ta tsyvil'noi bezpeky Ukrainy [Topical issues of technogenic and civil security of Ukraine] Materialy I Vseukrains'koi naukovoi konferentsii pedahohichnoho kolektyvu [Proceedings of the First All-Ukrainian Scientific Conference of the Teaching Staff]. Mykolaiv : Natsional'nyj universytet sudnobuduvannia im. Admirala Makarova, 21-23. Retrieved from http://dspace.mnau.edu.ua/jspui/handle/123456789/6414 [in Ukrainian].

Ця робота ліцензована Creative Commons Attribution 4.0 International License 